\title{
Long-distance Movement of a Dispersing Deer Mouse, Peromyscus maniculatus, in the Boreal Forest
}

\author{
Thomas S. Jung ${ }^{1}$, Kieran S. O’Donovan ${ }^{1}$, and Todd Powell ${ }^{2}$ \\ ${ }^{1}$ Yukon Department of Environment, P.O. Box 2703, Whitehorse, Yukon Y1A 2C6 Canada \\ ${ }^{2}$ Yukon Department of Environment, P.O. Box 194, Watson Lake, Yukon Y0A 1C0 Canada
}

Jung, Thomas S., Kieran S. O’Donovan, and Todd Powell. 2005. Long-distance movement of a dispersing Deer Mouse, Peromyscus maniculatus, in the boreal forest. Canadian Field-Naturalist 119(3): 451-452.

We report an apparent long-distance, non-homing movement of $3044 \pm 60$ m made by a dispersing subadult male Deer Mouse, Peromyscus maniculatus, in southeastern Yukon. Our observation is nearly twice the maximum distance previously recorded for non-homing Deer Mice, and apparently the longest dispersal movement recorded for this species.

Key Words: Deer Mouse, Peromyscus maniculatus, dispersal, movements, Yukon.

Despite the significance of dispersal in the spatial ecology and population dynamics of small mammals, the process is little understood (Fairbairn 1978; Bowman et al. 2001). Deer Mice (Peromyscus maniculatus) can move relatively long distances (e.g. $>1000 \mathrm{~m}$; Teferi and Millar 1993; Topping et al. 1997; Bowman et al. 1999, 2001; Rehmeier et al. 2004), yet reports of such movements are rare, likely due to a low probability of detection (Rehmeier et al. 2004). Here, we report an apparent record long-distance movement by a dispersing Deer Mouse in southeastern Yukon.

As a part of studies on small mammals in the boreal forest near Watson Lake, Yukon $\left(60.06^{\circ} \mathrm{N}, 128.70^{\circ} \mathrm{W}\right)$, we used Ugglan live-traps (Model 3 Lemming Special, Granhab, Marieholm, Sweden) and Longworth livetraps (Longworth Scientific Instruments Co., Abingdon, United Kingdom) to live-capture small mammals during summer and fall 2004. We live-trapped rodents at two study areas situated about $3 \mathrm{~km}$ apart. One trapping area (Area A) was located about $1 \mathrm{~km}$ $\mathrm{N}$ of Watson Lake, while the other (Area B) was about $3 \mathrm{~km} \mathrm{NE}$ of Watson Lake. Both study areas were in boreal mixedwood forest. Co-dominant tree species included White Spruce (Picea glauca), Lodgepole Pine (Pinus contorta), Trembling Aspen (Populus tremuloides) and White Birch (Betula papyrifera). Limited logging occurred in Area B 8-12 years prior to our trapping.

At Area A, we established 6 grids of 25 trapping stations $(5 \times 5$ layout; $10 \mathrm{~m}$ between traps $)$. We placed one Ugglan and one Longworth trap at each trapping station. Traps were operational for eight days with no pre-baiting. At Area B, we ran 14 grids of 48-49 trapping stations $(6 \times 8$ or $7 \times 7$ layout; $12 \mathrm{~m}$ between traps). One Ugglan trap was placed at each trapping station. Traps on these grids were pre-baited for two days and operational for three days. At both study areas, traps were $12 \mathrm{~m}$ apart, baited with rolled oats, peanut butter and a slice of carrot, and cotton bedding was provided. Each morning, captured animals were identified, weighed, sexed, aged, ear-tagged with a Number 1 Monel tag (National Band and Tag Com- pany, Newport, Kansas), and then released where they were caught.

On 11 August 2004, we captured a subadult male Deer Mouse (eartag \# 1027) in a Longworth trap at Area A. On 26 August 2004, 15 days after being originally captured at Area A, the mouse was recaptured in an Ugglan trap at Area B. Geographic co-ordinates $( \pm$ $30 \mathrm{~m}$ ) of the original capture location and the last capture location were obtained with a global positioning system (GPS; Garmin International Inc., Olathe, Kansas). We used a geographic information system (GIS; ArcView GIS 3.2, ESRI, Redlands, California) to calculate the distance moved by the Deer Mouse. GIS analysis provided a straight-line distance of 3044 $\pm 60 \mathrm{~m}$ between the two capture locations. Travel by the Deer Mouse was most likely through continuous boreal forest. The straight-line movement, or substantial variations thereof, indicate that the movement between capture locations was neither hindered nor facilitated by apparent barriers (e.g., rivers) or travel corridors (e.g., powerlines or roads), respectively.

No other investigators had trapped and ear-tagged small mammals in the area in the past five years, so it is unlikely that the Deer Mouse was from another study. Furthermore, our ear tags were prefaced with the code "YTG" before the numbering, which is distinctive in the field. Similarly, we are confident that the tag was not confused with another Deer Mouse ear-tagged on the grid where it was last recaptured, since none of the other five Deer Mice captured at this grid had tag numbers that were easily confused with \# 1027. We did not simultaneously trap at both study areas, and different field crews were doing the work at the two study areas, so we consider it unlikely that the mouse traveled in a vehicle or trap with a field crew from Area A to Area B. Given rejection of these potential alternatives, we conclude that the Deer Mouse did, in all likelihood, move a minimum distance of $3044 \pm 60 \mathrm{~m}$.

Bowman et al. (1999) recorded a long-distance dispersal movement of $1768 \mathrm{~m}$ by a subadult male Deer Mouse in forests in New Brunswick. In Kansas, Rehmeier et al. (2004) reported several Deer Mice mov- 
ing $>1000 \mathrm{~m}$, with a maximum recorded movement of $1320 \mathrm{~m}$. During homing experiments, several studies have reported human-induced movements of Deer Mice >1500 m (Murie 1963; Furrer 1973; Teferi and Millar 1993). In Alberta, Teferi and Millar (1993) reported one Deer Mouse had moved a straight-line distance of $1980 \mathrm{~m}$ during a homing experiment. Maier (2002) reported a female White-footed Mouse (Peromyscus leucopus) naturally moving a minimum of $14730 \mathrm{~m}$, and another female White-footed Mouse moving $6840 \mathrm{~m}$, between successive capture locations in Massachusetts. Therefore, our observation of a minimum movement of $>3000 \mathrm{~m}$ for a Deer Mouse is not inconceivable. To the best of our knowledge, our observation establishes the longest recorded movement of a Deer Mouse.

Given the time of year (early fall) and that the individual was a subadult male, we suggest that the observed movement represents dispersal from the natal range (Fairbairn 1978). The mechanisms behind dispersal in Peromyscus are unknown. Rodent populations may vary widely from year to year (e.g., Gilbert and Krebs 1991), and Bowman et al. (1999) and Maier (2002) had suggested that long-distance dispersal in Peromyscus in their study areas may have been influenced by high population densities. In our study, however, Deer Mouse abundance was 3.4 times lower in 2004 than in 2003; 2.01 individuals per 100 trap nights (TN) vs. 6.77 individuals per $100 \mathrm{TN}$, respectively (Jung et al. unpublished data). Therefore, there should have been much nearby, suitable, and unoccupied habitat for the Deer Mouse to establish a territory. Rehmeier et al. (2004), using multiple observations over nine years, also noted an inverse relationship between population density and propensity of Deer Mice to move long distances. They suggested that increased numbers of social fences at higher densities may result in decreased incidences of long distance movements by Deer Mice. Maier (2002) suggested that a lack of traditionally available food resources may also lead to notably long-distance dispersal. We have no data on food availability for murine rodents in our study area. Regardless of the mechanism or trigger, our observation substantiates the contention by Bowman et al.
(1999), Rehmeier et al. (2004), and Maier (2002) that small mammals may be more vagile than previously thought.

\section{Acknowledgments}

We thank K. Russell, J. Colbert, and R. Brodhagen for field assistance. M. O'Donoghue, B. Slough, D. Nagorsen and two anonymous reviewers kindly reviewed an earlier draft of this note. We thank the Yukon Department of Environment for its continued support of wildlife research.

\section{Literature Cited}

Bowman, J. C., M. Edwards, L. S. Sheppard, and G. J. Forbes. 1999. Record distance for a non-homing movement by a Deer Mouse, Peromyscus maniculatus. Canadian Field-Naturalist 113: 292-293.

Bowman, J. C., G. J. Forbes, and T. G. Dilworth. 2001. Distances moved by small woodland rodents within large trapping grids. Canadian Field-Naturalist 115: 64-67.

Fairbairn, D. J. 1978. Dispersal of Deer Mice, Peromyscus maniculatus: proximal causes and effects on fitness. Oecologia 32: 171-193.

Furrer, R. K. 1973. Homing of Peromyscus maniculatus in the Channelled Scablands of east-central Washington. Journal of Mammalogy 54: 466-483.

Gilbert, B. S., and C. J. Krebs. 1991. Population dynamics of Clethrionomys and Peromyscus in southwestern Yukon, 1973-1989. Holarctic Ecology 14: 250-259.

Maier, T. J. 2002. Long-distance movements by female whitefooted mice, Peromyscus leucopus, in extensive mixedwood forest. Canadian Field-Naturalist 116: 108-111.

Murie, M. 1963. Homing and orientation of Deer Mice. Journal of Mammalogy 44: 338-349.

Rehmeier, R. L., G. A. Kaufman, and D. W. Kaufman. 2004. Long-distance movements of the Deer Mouse in tallgrass prairie. Journal of Mammalogy 85: 562-568.

Teferi, T., and J. S. Millar. 1993. Long distance homing by the Deer Mouse, Peromyscus maniculatus. Canadian FieldNaturalist 107: 109-111

Topping, M. G., J. S. Millar, and B. E. Woolfenden. 1997. Unsuccessful colonization of a naturally depopulated area by the Deer Mouse, Peromyscus maniculatus. Canadian Field-Naturalist 111: 466-469.

Received 17 September 2004

Accepted 8 September 2005 